\title{
Alena Biełaja
}

Baranawicki Uniwersytet Państwowy

https://orcid.org/0000-0002-4328-6200

\section{Мастацкая канцэпцыя асобы ў прозе Міры Лукшы}

Жыццё чалавека ў народзе і жыццё народа ў свеце, чалавек, прырода і грамадства у іх узаемадзеянні з'яўляюцца, адзначае Ю. Бораў, вечнай тэмай і прадметам літаратуры. Шчасче людзей, развіччё грамадства не насуперак $і$ не за кошт, а праз асобу індыьвіда ёсчь устойлівае ў ідэалах літаратуры ${ }^{1}$. Мастацкая канцэпцыя асобы, у сукупнасці азначэнняў, - гэта рэалізаваная на розных узройнях літаратурнага тэксту аўтарская ідэя як сістэма поглядаў на свет і чалавека ў свеце: яго сацыяльную прыроду, ролю $\ddot{y}$ культурным жыцці, індывідуальныя рысы, якія раскрываюцца ў працэсе грамадскіх адносін. У адрозненне ад філасофскай, сацыялагічнай, псіхалагічнай канцэпцый гэта ёсць пазіцыя аўтара, увасобленая $\breve{y}$ мастацкіх творах, вынік складанай творчай працы пісьменніка над асэнсаваннем духойнага і матэрыяльнага аспектаў жыцця. Мастацкая канцэпцыя асобы ўключае таксама прынцыпы адлюстравання аўтарскіх поглядаў, трансфармацыі ўражанняў і імпульсаў падсвядомасці пісьменніка у паэтычныя вобразы. Сярод вытокаў мастацкай канцэпцыі асобы вылучаюцца грамадска-філасофскія (жыццё народа, яго гістарычны вопыт, этыка, мараль); навукова-філасофскія (гнасеалогія, анталогія, псіхалогія і інш.); літаратурна-эстэтычныя (фальклор, эстэтычныя плыні, літаратурныя традыцыі); сямейна-побытавыя (сувязь з бацькоўскімі і мацярынскімі

1 Ю. Борев, Эстетика, Москва 1997, с. 530. 
кодамі, уражанні ад кантактай з блізкімі людзьмі, сямейныя традыцыі, міфы і г. д.).

Кожны пісьменнік па-свойму, з невядомага боку раскрывае канцэпцыю свету і асобы. У ідэале аўтарскія адносіны павінны вызначацца не знешнімі абставінамі, а творчымі прынцыпамі, якія грунтуюцца на

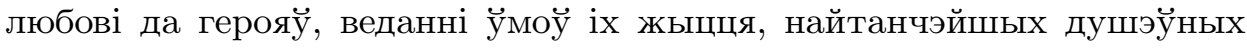
рухай, на дасканалым валоданні словам. Вельмі каштоўным у літаратуры з'яўляецца нацыянальнае ўзнайленне свету і ўспрыманне яго асобай.

Аснову мастацкай канцэпцы асобы складае нацыянальны характар, а яго адметнасцю абумойлена сістэма асабовых і міжасабовых адносін літаратурных персанажай як своеасаблівых нацыянальных стэрэатыпаў. Гэта адносіны да ўласнай асобы, жыцця і смерці, да жыццёвых выпрабаванняў, да традыцый і новага, да радзімы, да прыроды і працы, жанчыны (мужчыны), кахання, сям'і, бацькоў і дзяцей, да людзей (суседзяў), да зямлі і ўласнасці, да жывых істот, да ведай, вучобы і вучоных, да рэвалюцыі і вайны. А. Бабарэка сцвярджаў, што свет сатканы з дачынення ў, і складанасць іх выявіў метафарычна: Людзі стаяць адзін да аднаго або тварам $к$ твару, або задам $\kappa$ заду, або тварам $\kappa$ заду иі задам $\kappa$ твару ${ }^{2}$ У прааналізаваным намі зборніку прозы Міры Лукшы "Бабскія гісторыі" адбілася вялікая разнастайнасць падобных дачыненняў, у тым ліку і пазбаўленых метафарычнасці, асабліва у дачыненнях паміж жанчынамі.

Істотны складнік мастацкай канцэпцыі асобы - эстэтычны ідэал. Ён прысутнічае у вобразах персанажаў, якія ствараюцца рамантычнымі або рэалістычнымі сродкамі. Пры паказе супярэчлівых характараў ідэал выражаецца як аўтарская пазіцыя, і гэта актывізуе такі элемент канцэпцыі, як адносіны аўтара да персанажа. Ідэал у творы - мэта, да якой імкнецца герой. Ідэал многіх вясковых персанажаў Міры Лукшы - багатае і працавітае жыццё, як у пана Кавальскага (апавяданне “Марысенько, не ўмірай!"). Ідэал жаночай прыгажосці рэпрэзентаваны у розных варыянтах і ўрэшце зводзіцца да такога: краса - не найважнейшая справа (163). Параска з твора "Спосаб на поспех у каханні" у дзейках не найхарошчая з твару была, але баба ўдалася добрая, анёл, а не чалавек, $i$ гаспадыня дай божа... ${ }^{3}$ Звяртае на сябе ўвагу і такі

\footnotetext{
2 А. Бабарэка, Збор твораў. У 2-х т., Вільня 2011, т. 2, с. 381.

3 М. Лукша, Бабскія гісторыі, Беласток 2001, с. 163. Далей пры спасылцы на гэта выданне $\ddot{y}$ дужках падаецца старонка. Выдзяленне тэксту ў цытатах належыць аўтару артыкула.
} 
аспект сямейнай канцэпцыі: калі сталы мужчына ўзяй за жонку маладую, то павінен яе жыць навучыць, запанаваць над ёю, а не адразу кідаць! (14).

Катэгарычныя імператывы беларускага існавання, сфармуляваныя К. Чорным, - трэба жыць, трэба варушыцца, трэба пачынаць усё спачатку. Персанажы беларускай прозы традыцыйна выяўляюць утрапёнасць, нават драпежнасць, у працы, найперш у працы на зямлі. Героі Міры Лукшы у большасці сваёй таксама людзі иягавітыля да прачь (35). Настуля з аднайменнага апавядання вельмі ж ужо уиэпістая да праџьл... Як рушыць на загоны, то $і$ маладзіча з ёю не ўрравічиа. Зямля гарэла ёй у далонях (31). I ў старасці Настуліна гаспадарка дагледжана, на палетку выраблена кожная грудка. Зямля забяспечвае селяніну, як заўважыў у свой час Глеб Успенскі, невыносную лёгкасць быцця. Кожная пара года вымушае яго варушыцца у тым ці іншым напрамку. Коля і Надзя з апавядання Міры Лукшы "Піліп у фасолі" ўжо і стараватыя, і гаспадарка ім ужо уелася у косці. Але калі толькі прыгрэе веснавое сонейка, запахне свежай зямлёй $i$ гноем, зазвініць жаўрук, гаспадар ажывае, бегае на падворку, клапоціцца, рыхтуецца да ворыва. Коля з крэктам лезе на трактар, Надзя коціцца за ім услед і таксама ўсцягвае на трактар сваё поўнае, хоць ужо і не такое дужае цела... Раман, загалоўкавы герой аднаго з апавяданняў, увесь век добры гаспадар быў. Без зямлі жыџь не можа, рукі склаўшь... Хоць і пенсіянер, а калупаециа ў зямлі, сее, збірае, гадуе. Tайчэица (55). Аднак падобная ўчэпістасць у працы не заўсёды з'яўляецца ўхвальнай. Як адзначае пісьменніца, яе героі Несцеры (апавяданне "Чорт у хаце") налягалі на работу як дурныя. Нават у святую нядзелю, калі пагода стаіць, ехалі ў поле ці на луг, не шануючы святых, нібыта паганцы.

Адносінамі вясковых персанажаў да працы на зямлі традыцыйна вызначалася іх стаўленне да вучобы. Нашто рольніку школа? Хопіиь ведаць тое, што дзяды ведалі, каб зямля радзіла. Тады з голаду не памрэш, абы табе панства жыць давала (113). Так навучалі бацькі Адама Засімюка ("Горкая вада"). А цяпер, кажа ён, каб быў маладзейшы, то і сам бы пайшоў вучыцца, бо час змяніў каштоўнасці. Ясь (апавяданне "Добрая Маруся") застаўся на гаспадарцы, бо да вучобы быў не вельмі здатны. Як кажуць, не было б бацькам шчасця, ды няшчасце дапамагло: Дзякаваць Богу $i$ за такое, а можа пери якраз за ўсё за тое, што астайся памочнік дома... (5).

Чалавек, упэўнены сталыя героі Міры Лукшы, хоча даўжэй быць патрэбным, хоць якую льюку памьиь, які куль звязачь иі ў агаро- 
дзе летам пагартачиа. Бо іначай усё на чалавеку заклякне, калі рук ды ног не ўжываеш, ды і розум не так прачуе, калі каменем на канапе сядзіш, не абатрэшся з людзьмі... (7). (У К. Чорнага ёсць выраз паміж людзей вытруся.). Таму так цэніцца талент натуральнага і простага кантакту з людзьмі (9), які ёсць, да прыкладу, у Нюркі (апавяданне "Не мела баба... дзеда"). Яна загаварыць да кожнага ўмее... (8), не раўня некаторым: ёсць на што паглядзець, пакуль рот не раскрые! I асабліва гэта датычыць мужчынскай паловы чалавецтва. 3 Марылькай (апавяданне "На сваім") прыемна было у лес пайсці, сцвярджае аўтарка-апавядальнік. Такая людская, спагадлівая, разумная кабета, што нават калі і грыбоў не назбіраеш, то часу не страціш, бо паразмаўляеш з ёй - і неяк лягчэй на сэрцы зробіцца. Кабеты у вёсцы, адзначае М. Лукша, увогуле таленавітыя на слова (90). Сонька (апавяданне "Хата") на тое язык у роце мае, каб сваё сказаць; здольна адбрахацца, калі трэба.

Значнае месца $\ddot{y}$ мастацкай канцэпцыі персанажаў прозы Miры Лукшы займаюць стасункі паміж суседзямі. Як кажуць, пакуль свой паспагадае, то чужы пашкадуе. Раман з аднайменнага апавядання чалавек добры, з суседзьмі добра жыве. I добра было б, каб так $i$ да канца (55). Але гэта ідэальная норма. Часцей за ўсё суседзі - добрыля людзі у значэнні абылкавыля, ці ў тым, якое ўклаў у гэты выраз Т. Шаўчэнка (не так тыля ворагі, як добрыля людзі...). Калі аўдавей Філіп (апавяданне "Не мела баба... дзеда"), адзначае аўтар, усе яму спачувалі... але ніхто не спяшаўся з дапамогай (9). У суседскіх стасунках мае дзейснасць катэгарычны імператыў ніколі не суньче носа у чужыя сямейныя справы (10). Беларус асцерагаецца ўткнущь язык у чужую кашу ${ }^{4}$ : не з яго суседзі пачалі сварку, не яму і суцяшаць. Першы раз здарылася ў вёсцьи, каб суседзі захачелі мець дачыненне да чужое справы (32), адзначае Міра Лукша, калі нашчадкі аўдавелага Максіма Лапуцкага памкнуліся жорстка перашкодзіць яго шлюбу з Настуляй.

Адметнасць нацыянальнага светабачання беларусаў у многім вызначаецца ix талерантнасцю. Вёска Лазова славіцца тым, заўважае пісьменніца, што жьввуц тут людзі спакойныля, памяркойньля, самавітыл, проста людскія (115). Аднак празмерным было б сцвяр-

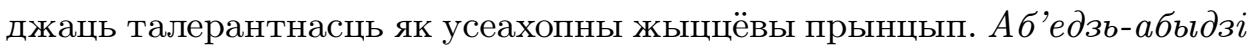
ўсе вёскі Беларусі нашай $і$ не знойдзеш той хать, дзе б злагада што-

4 Л. Калюга, Творы, Мінск 1992, с. 89. 
дзень была... Спрачаючиа, сварачиа... ${ }^{5}$ - напісаў у 1920-я гг. Л. Калюга. Далёкі ад ідыліі і паказ рэчаіснасці за межамі вёскі Лазова. Сяляне сварыліся то за сабак, то за свіней, то за абкошаную палоску... (147). Бабы - то за яйка, што свая курыца згубіла ў чужой крапіве, то за гузак на галаве дзіцяці. А найчасцей - за межы.

Найбольш распаўсюджаны герой беларускай прозы - сярэдні чалавек: 3 тых, што раскошы не бачылі, але і гора не зналі. Гэтая рыса адбілася і у паводзінных стратэгіях персанажаў Міры Лукшы. Стары Аніс (апавяданне "Чалавечыя словы") чэnае сабе паціху па свеце, уголас не плача, міласці не просіџь (139). Нават цвыркун, загалоўкавы персанаж аднаго з твораў, забраўшыся ў хату дзеда з бабай, не гаруе, хоць і цешыциа няма иылм (72), ды чакае сабе вясны.

Нягледзячы на спрадвечнае «Асадзі назад!», беларусы захойваюць адметнае пачуццё ўласнай годнасці. «Xай ты голь $i$ розум у иябе не першы, чаго з сябе рабіџь блазна перад чужьлмі? ...Гонар мець якісь трэба» (112).

У апавяданнях пісьменніцы выразна адлюстраваўся погляд яе немаладых герояў на фінал жыцця. I ён традыцыйны для беларускай этнічнай прасторы. «Эгэ, смерџь не такая страшная. Ды і пара ўжо мне...» (70), - кажа баба Нюра ў апавяданні "Старэнькія". Не страшна ісці на сустрэчу з невядомым і бабе Вольцы ("Волька і смерць"). Гумар, як пісаў Р. Гары, - надзвычай удалы і беспамылковы спосаб абяззбройваць рэчаіснасць у той час, калі яна гатова раздушыць чалавека, і сведчыць аб чалавечай годнасці, перавазе над абставінамі. Беларусы, як паказвае айчынная літаратура, здольны з гумарам ставіцца нават да смерці (у прозе першай трэці ХХ стагоддзя гэта асабліва яскрава прад'яўлена ў мастацкім дыскурсе Лукаша Калюгі). Паставіла Волька труну пасярод святочна прыбранага пакоя, вазонамі і букетамі акружыла... Абулася у н новыя боцікі, нацягнула сукенку. Падставіӱшы услончык, ускараскалася да труны, падварушыла падушачку, запаліла свечку і ўмясцілася у дамавіне, як у калысцы, склаӱшы рукі на грудзях. Яшчэ і падумала: а цікава, як гэта збоку глядзіцца? Усё было акуратна, па-людску, як яна і хацела, - запэўнівае аўтар. Памаліӱшыся, Волька, супакоеная, заснула. Праз гадзіну суседка разнесла вестку пра яе смерць, але насамрэч на той, лепшы бок свету (84) Вольку, кіруючыся яе сцэнарыем, праводзілі людзі праз тыдзень. Зусім не так адышоў у іншы свет Лявон Квяткоўскі (апавяданне "Хата з краю"): як сядзеў у сваім самотным жытле за сталом, так і заснуй навекі, і цэлы ты-

5 Тамсама, с. 133. 
дзень ніхто з родных яго не спахапіўся... У некаторых творах адметна ўвасоблены матыў, так скажам, сацыяльнай бессмяротнасці. Дзед мочнага Янака Анісім пасадзіӱ яблыні ӱ 1912 годзе сабе на славу, унукам на скаштаванне (101), як любіла казаць баба Аўдося.

Звяртае на сябе ўвагу і такі аспект дачыненняў персанажаў з рэчаіснасцю, як адносіны да жывёлы. Найперш гэта звязана з адзінокім жыццём многіх вяскойцаў сталага веку. ...Песияць звярой шмат хто з самотньх людзей (73), - справядліва заўважае Міра Лукша. Калі Ігнась ("Дом Паўліны") схапіӱ вернага сабаку за карак, падняў уверх і пацалаваў у спалоханую засліненую морду (49), то здзівіўся гэтаму, бадай, толькі сам сабака. Звяры і дзеці праводзяць да шашы дзівакаватую Газьбету, якая заўсёды мае ӱ сваіх торбачках сякі-такі пачастунак для тых і другіх. Звер - пад Божай апекай, разважае баба Сасанна. I грэх такому брыду рабіџь, бо не дасць Тварэи пакрыудзіиь бездапаможнага (93). Усім добра ў Сасанчынай гаспадарцы, хіба адно мышам не. Людскасць вяскойцаў баба Сасанна вымярае іх адносінамі да жывёлы. Зусім не такі быў яе муж Антоні, што да жывёлы ставіўся як да парабка. Конь - жывёла далікатная, крыудлівая, а ён б'е яго, як у мех (92). А некалі у яе вёсцы такія скнары жылі, што за страву біліся пры сямейнай місцы, замест таго, каб лішнюю жменю круп у чыгунок пакласці, каб хапіла і хатнім, і таму коціку ці сабаку, каб укінуць не сухой свіной стравы, а таго, што сам ясі, закрасіӱшы малаком ці скваркай. Ды і звер умее аддзячыць за дабрыню. Страшным чалавекам выявілася для Антона Аліферука Марыся, якая пачаставала галубоў атручаным зернем, каб не брудзілі яе чысты, уквечаны балкон. Адметна ӱведзены пісьменніцай фальклорна-міфалагічны матыў у апавяданні "Чалавечыя словы": іх немаўля пачула ў святочны вечар ад старога сабакі і ўпершыню зразумела...

Адна 3 дамінант мастацкай канцэпцыі асобы беларуса - патрыятызм месца. Гэтае пачуццё перажываецца не толькі кожным героем індывідуальна (Андрэю з апавядання "Добрая Маруся" у Беластоку дыхачь ияжка, не тое што пад пушчай - ано жыві (6), але і ўведзена y гістарычны кантэкст. Дзед Антон, адзначае пісьменніца ў апавяданні Да апошняе крыві, перажыў пару войнаў, бунтаў $i$ мардабояў ад міжнародных, міжнацыянальных да міжсуседскіх.. (147-148). Сярод мастацкіх носьбітаў праблемы патрыятызму ў прозе Міры Лукшы вылучаецца матыў бежанства. Пісьменніца згадвае, як на вяселлі (апавяданне "Раман і Юля") спачатку спяваліся польскія песні, а потым ужо пайшлі нейкія рускія, пачынаючы з "Бадзягі", што старыя прывезлі з бежанства. Бабе Нюры пра яе бежанскую маладосць нагадвае смак 
рыбы, якую лавіла ў рэчцы Омцы. Кастэнцікаў у бежанства гісторыя адправіла салідньмі гаспадарамі, якія мелі што шкадаваџь, беручь у далёкую невядомую вандройку жменю дабытку. (...) Было што кідаџь, i старыля мужыкі без аглядкі, каб не плакаць, пайшлі на ўсход; галасілі і маліліся бабы, выносячы іконы. Вярнуліся ж на ўдзірванелае поле $i$ збітыл былыля сенажаці (79). Гэлька Місюкова з бацькам з Самары вярнуліся, у стэпе пахаваўшы матку, памерлую ад тыфу, выдзерлі з каранямі лазу ды бярэзнік, што ўварваліся на іхні палетак, выбралі камяні (80), каб, паводле беларускага фатуму, пачынаць усё спачатку. Сям'я Мацюкевічаў (апавяданне "Скарб") вярнулася ӱ 1923-м на парослыя буйным зеллем і маладымі дрэўцамі руіны, бо, пасля сыходу гаспадароў у паняверку, згарэла ўся вёска. Адзначым, што часам нават прычынай спрэчак за межы і платы было, як адзначае аўтар, жаданне нічога не страчічь з бачькойскае спадчьинь, з таго, да чаго вярталіся з далёкага свету (81). Каго гісторыя адправіла ў Сібір, каго у Нямеччыну... Баба Сасанна была дачкой гаёвага, і калі яе, маладую, прыехалі у Сібір забіраць, цэлы тыдзень у каноплях хавалася, не піўшы, не еўшы. Калі прыйшлі немцы, то дапытваліся, хто пры саветах даносіӱ і спіскі складаў на вывозку. Але яна не выдала суседа, бо у яго было чацвёра малых дзяцей. Вось і не мае жанчына на сабе таго граху, што хтосьиі праз яе загінуў (94).

Як разважае 3. Бядуля у апавяданні "Пяць лыжак заціркі", шчасие не мае сваёй асобнай меркі для ўсіх людзей на свече, але кожнь чалавек мае сваю асобную мерку да шчасия $і$ свой асобны погляд на самое шиасце... Адпаведна, і няшчасие не мае сваёй асобнай меркі для ўсіх людзей на свече, але кожны чалавек мае сваю асобную мерку да няшчасия $i$ свой асобны погляд на самое няшчасце 6 . Надзвычай арганічна гэтыя сентэнцыі стасуюцца да зместу і пафасу апавядання Міры Лукшы "Пад акупацыяй". Калецтва бабы Ніны засцерагло яе ад вывазу у Нямеччыну і $\ddot{y}$ гэтым яе шчасце. Але не ўее так проста: паводле яе разваг, калі б не вайна, то Ганс $і$ Сонька не сустрэліся б. Калі б не вайна, Ганс не дастаў бы кулі ў лоб за каханне з дзяўчынай рабскае расыл. Калі б не вайна, іначай выцлядаў бы сённяшні свет (20). Уцячы, схавацца закаханым не было куды, усюды вайна, фашысты па уссёй Еўропе. Ой, які лёс страшнь!! (...) Гэта ж як здзек над чалавечьлм сэриал! Ну, але калі б не пайшлі немиь на нас вайной, иі спаткаліся б Сонька з Гансам... (23). I не меў бы дзед Міша ўнучку Гражынку, у якой хоць і цячэ ненавісная нямецкая крой, але гэтая дзяўчынка адзі-

6 З. Бядуля, Пяць льжак зачіркі, [у:] Салавей, Мінск 2000, с. 159. 
ная, хто яму на старасці радасць прыносіць... Амаль па Шапенгаўэру: дзякуй табе, хвароба за тое, што дапамагаеш цаніць жыццё.

3 праблемай шчасця цесна звязана праблема фатуму, лёсу. Беларусам уласцівы так званы стыхійны фаталізм. Што ж зробіш... Не сам жа чалавек свой лёс выбірае. 3 лёсам на гэты свет прыходзіш (47). Нават звон, разважае Анюта ў час пахавання мужа (апавяданне "Агледзіны"), нашто больш трывалы за чалавека, а і той, калі давядзецца яму ўпасці з вежы, таксама разваліцца. Не назвонішся, калі лёс не дасиь... (127).

3 пункту погляду іншага персанажа, каб так кожны думаў, то свет зусім не змяняусся б! (47-48). I ўвогуле - Не выгаварвай лёсу тое, што прыносічь, лепш адразу дагаварыся $з$ ім адносна ўмоў $i$ варункаў (110). Героі-беларусы маюць-такі здольнасць хоць неяк угаварыць ці загаварыць лёс. I калі нават не слухае ён иябе, то ў рэшие рэшт абрыднеш яму, як тая назойлівая муха. I калі не прыхлабушчыць мухабойкай, то мо выжане ручніком, а кыш! - ляиі, паскуда, сваёю дарогай! (109).

Беларус асноӱвае сваё жыццё на трох кітах: трываласць, зручнасць, прыгажосць. На апошнім хочацца прыпыніцца асабліва. У хаце бабы Зулькі («Адпачывайце, бабо»), хоць ёй ужо амаль 80, - як у шклянцы. Чысценька, прыемна. А старая Аўдося дык захацела на столі намаляваць сонца і воблачкі - каб цікавей было ("Аўдосіна неба"). Студэнты-практыканты з мінскай акадэміі выъелі на бабулінай столі і сонца, як жьвое, паўднёвае, гарачае, $і$ воблачкі белья, $і$ бурыя хмары, і ружовыя, як пад захад, а сярод іх нават самалёчік иягне белую смужку, а над печкай - срэбны маладзік сярод зорак (39). Разам цешыліся, смяяліся, і доўга Аўдося, лежачы ўжо нядужай і гледзячы на сваё неба, успамінала тую радасць, той смех. I сапраўды, шчаслівымі нас робіць наш погляд на свет і адносіны сэрцаў... Таму кожны, хто хоча быць шчаслівым, мае такую магчымасць. У шэрагу твораў праводзіцца думка, што самотная старая жанчына ўсё ж лепш дасць сабе неяк рады (9), чым мужчына, які апынуўся ў такім стане. Яму бывае вельмі цяжка дайсиі да сябе (26). Адзін з мастацкіх маркёраў падобнага стану - ...Хата была ў руіне (9).

Беларусам не ўласціва жаданне па судах цягацца, у тым ліку i таму, каб не марнаваць часу, прызначанага на гаспадарку. Раман, загалоўкавы герой апавядання Міры Лукшы, і не судзіўся, і за свед-

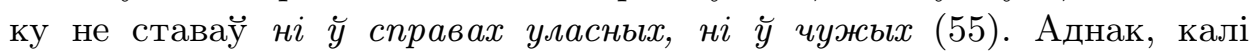
ўзнікла патрэба засведчыць невінаватасць суседкі, сумленне паклікала яго ў дарогу. 
Нацыянальнае адлюстраванне свету непадзельна 3 яго каларытным моўна-выяўленчым ӱзнаўленнем, а гэта адзін са складнікаў мастацкай канцэпцыі асобы. Пласт філасофскіх сентэнцый, фразеалагізмаў, у тым ліку трансфармаваных, кленічаў, яскравых эпітэтаў і параўнанняў, крылатых выслойяў, якія бяруць выток у традыцыйнай вуснай творчасці беларусай, у творах Міры Лукшы настолькі багаты, што заслугоўвае асобнага даследавання. Нельга было прайсці міма такіх формул, як ...Вядома, людзі, як і рэчьл, - псуюича (143); Kaжуџь, у каго хата з краю, той $і$ чіха сядзіџь, нічога не бачыць (147); Каб выл... на гарэ стаялі і сонца не бачылі! (149); А дзяціскаў некалі ў вёсках было столькі, што школь $\check{y}$ швах трашчалі!

Падводзячы вынік аналізу мастацкай канцэпцыі асобы ў празаічных творах Міры Лукшы, варта адзначыць багацце чалавечых узаемаадносін, рэпрэзентаваных пісьменніцай, яе ӱвагу да ключавых каштоўнасцей жыцця персанажаў, а гэта праца, каханне, сям'я, міжасабовыя (у тым ліку суседскія) стасункі. Пад увагай аўтара знаходзіцца праблема жыциё/ смерць як важнейшая дыхатамія (Э. Фром) чалавечага існавання, дыялектычныя адносіны персанажаў да фіналу жыцця і да сутнасці сацыяльнай бессмяротнасці. Значнае месца займае праблема чалавечага шчасця ӱ яе непарыўнасці з праблемай фатуму. Супастаўленне асобных складнікаў канцэпцыі асобы ў творчасці прадстаўніцы аб'яднання "Белавежа" і ў беларускай прозе першай трэці XX стагоддзя дае ўяўленне пра агульнасць іх вытокаў і традыцыйных асноў.

\section{I T E R A T U R A}

Babareka A., Zbor tvoraŭ. U 2 t., Vil'nja 2011, t. 1 [Бабарэка А., Збор творай. У 2 т., Вільня 2011, т. 2].

Borev Ju., Ehstetika, Moskva 1997 [Борев Ю., Эстетика, Москва 1997].

Byadulya Z., Salavej: Apovest', apavyadanni, Minsk 2000 [Бядуля 3., Салавей. Аповесць, апавяданні, Мінск 2000].

Kalyuga L., Tvory: Raman, apovestsi, apavyadanni, listy, Minsk 1992 [Калюга Л., Творы, Мінск 1992].

Luksha M., Babskija gistoryi, Belastokv 2001 [Лукша М., Бабскія гісторыі, Беласток 2001]. 
S U M M A R Y

\section{ARTISTIC CONCEPT OF AN INDIVIDUAL IN MIRA LUKSHA'S PROSE}

All components of the artistic world of literary works are medium of artistic concept. In contrast to the ideas of the image, the character, and the hero, the concept refers to the writer's views; it optimizes the analysis of pictorial structure of a literary work. Scientific interest in the study of the characters' conception in literature was intensified at the turn of the 20th and 21st centuries and has been relevant since then. An artistic expression of a personality conception in literary works has clear historical and national features. This article presents the results of the analysis of the artistic concept of the personality in Mira Luksha's prose.

Key words: artistic concept of an individual, literary character, aesthetic ideal, national picture of the world, categorical imperatives.

\section{S T R E S Z C Z E N I E}

\section{ARTYSTYCZNA KONCEPCJA JEDNOSTKI W PROZIE MIRY ŁUKSZY}

Wszystkie komponenty świata artystycznego w literaturze są nośnikiem twórczej koncepcji. W przeciwieństwie do pojęcia obrazu, charakteru, bohatera koncepcja twórcza odnosi się do całokształtu poglądów pisarza, optymalizuje analizę obrazowej struktury utworu. Zainteresowania badaczy koncepcją bohaterów w twórczości poszczególnych pisarzy przybrały szczególnie intensywną formę na przełomie XX i XXI wieku, i trwają do dziś. Twórcze uosobienie koncepcji jednostki w utworze literackim posiada wyraźne cechy historyczne i narodowe. W artykule omówiono wyniki analizy artystycznej koncepcji jednostki w prozie Miry Łukszy.

Słowa kluczowe: artystyczna koncepcja jednostki, charakter literacki, ideał estetyczny, narodowy obraz świata, imperatywy. 